\title{
Neurology and Don Quixote
}

\author{
Jose-Alberto Palma ${ }^{a}$ Fermin Palma ${ }^{b}$ \\ ${ }^{a}$ Clinical Neurophysiology Section, Department of Neurology, University Clinic of Navarra, Pamplona, and \\ ${ }^{\mathrm{b}}$ Fellow of the Royal Academy of Medicine of Granada, Granada, Spain
}

\section{Key Words}

Neurology • Don Quixote de la Mancha - Miguel de

Cervantes $\cdot$ Renaissance $\cdot$ Literature $\cdot$ History of Medicine

\begin{abstract}
Don Quixote de la Mancha, which is considered one of the most important and influential works of Western modern prose, contains many references of interest for almost all of the medical specialties. In this regard, numerous references to neurology can be found in Cervantes' immortal work. In this study, we aimed to read Don Quixote from a neurologist's point of view, describing the neurological phenomena scattered throughout the novel, including tremors, sleep disturbances, neuropsychiatric symptoms, dementia, epilepsy, paralysis, stroke, syncope, traumatic head injury, and headache; we relate these symptoms with depictions of those conditions in the medical literature of the time. We also review Cervantes' sources of neurological information, including the works by renowned Spanish authors such as Juan Huarte de San Juan, Dionisio Daza Chacón and Juan Valverde de Amusco, and we hypothesize that Don Quixote's disorder was actually a neurological condition. Although Cervantes wrote it four centuries ago, Don Quixote contains plenty of references to neurology, and many of the ideas and concepts reflected in it are still of interest.
\end{abstract}

\section{KARGER}

Fax +4161306 1234

E-Mail karger@karger.ch

www.karger.com
2012 S. Karger AG, Basel

0014-3022/12/0684-0247\$38.00/0

Accessible online at:

www.karger.com/ene

\section{Introduction}

In 1605, Miguel de Cervantes (1547-1616) published, in Madrid, the first volume of his novel El ingenioso hidalgo don Quijote de la Mancha, popularly known as Don Quixote, which is considered one of the most important and influential works of Western prose, rivalled only by the Bible for the number of languages into which it has been translated. The second volume was published a decade later, in 1615 (fig. 1).

The plot of Don Quixote is extraordinarily complex. The hidalgo himself has the noble intention of dedicating his energies to the service of the moral order, being urged to do so by the sublime precepts of goodness and beauty embodied by his platonic beloved, Dulcinea del Toboso. Don Quixote has the task of righting wrongs, redressing injustices, aiding widows and orphans, protecting maidens, defending the oppressed, and so forth. His intention, being impracticable in this world of reality, is frustrated by earthly impediments, represented by the character of Sancho Panza, a simple peasant who cannot escape the noble influence of his master. The scheme of Don Quixote, which has become an integral part of occidental civilisation, reflects many universal problems which, due to their complexity, cannot be contained in any simple or unilateral interpretation: Don Quixote and his moral counterbalance, Sancho, are, at the same time, literary satire, so- 


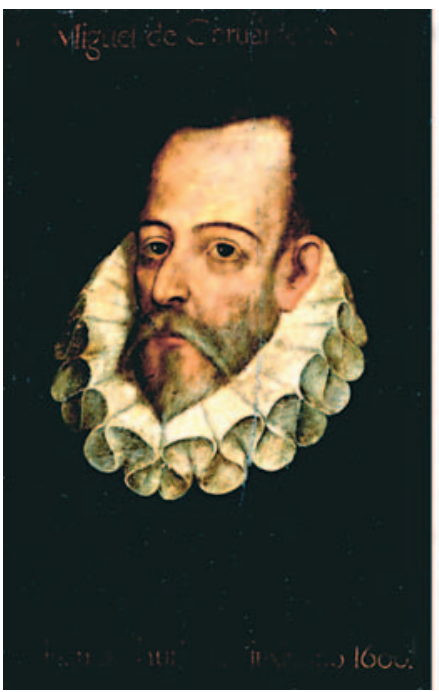

E L I N E E I O S O HIDALGO DON Q VIXOTE DE LA MANCHA,

Compuefo por Miguel de Ceruantes Saluedra.

DIRIGIDOAL. DVQVE DE BEIAR.

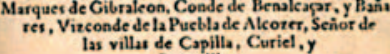
las villa de Capilla,
Burguillor.

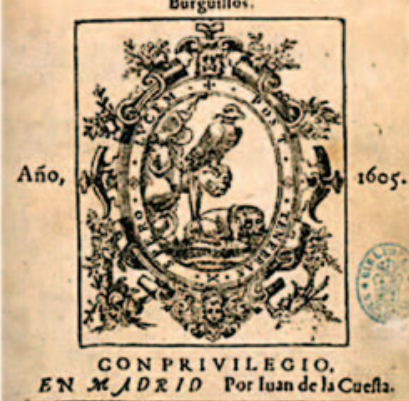

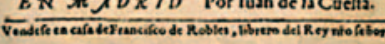

Fig. 1. Portrait of Miguel de Cervantes, attributed to Juan de Jáuregui (1600) (left). Front cover of the first edition of part I of Don Quixote (1605) dedicated to the Duke of Béjar and printed by Juan de la Cuesta, in Madrid (right).

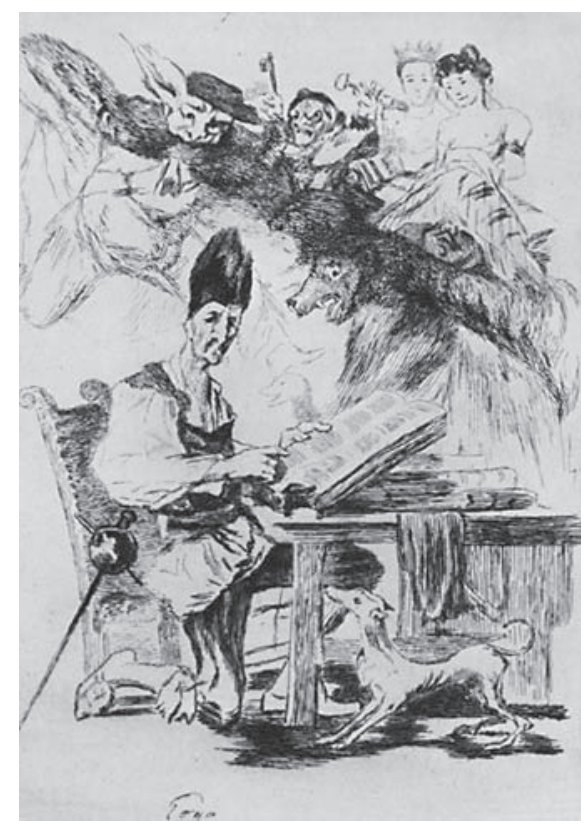

Fig. 2. Over the centuries, Don Quixote has exerted a deep influence on art and has fascinated most of the great Spanish masters. Aquatint print by Francisco de Goya (1746-1828) illustrating the first chapter of the first book: 'with little sleep and much reading his brains got so dry that he lost his wits'. cial criticism, a mirror of the decadent splendour of the Spanish Empire, and an echo of the everlasting conflict between comedy and tragedy, dream and reality, madness and sanity, and idealism and earthly materialism.

An amazingly large number of studies, ranging in scope from the monograph to the comprehensive work, have appeared in the past decades on Cervantes and his masterpiece, Don Quixote. Besides, the influence of Don Quixote on the creative works of writers (such as Borges, Dostoyevsky, Joyce, or Twain), musicians (Purcell, Richard Strauss, or Manuel de Falla) and painters (Goya, Picasso, or Salvador Dalí) is remarkable and well known (fig. 2).

Don Quixote has also exerted a deep influence in medicine. In fact, the repercussions of Don Quixote in the works of eminent physicians is noteworthy. Thomas Sydenham, known as the English Hippocrates, counselled his disciple Richard Blackmore to read Don Quixote to become a better doctor [1]. Sir William Osler, often called the 'father of modern medicine' for his contributions to the development of medical education, included Don Quixote in his recommended list of bedside books for medical students [2]. At the age of 27, Sigmund Freud wrote to his future wife, Martha Bernays, about the deep impression left on him by his reading of Don Quixote in Spanish [3]. About that time, Freud was wondering whether to follow his neuroscientific research and become a neuroscientist (understood as an analogy of the quixotic ideal) or to devote himself to the well-paid private medical practice (an analogy of Sancho, as a reality principle). Santiago Ramón y Cajal discovered Don Quixote at the age of 12, but he did not really enjoy a novel in which the hero suffered so many setbacks. This initial impression changed radically during his life, as it can be deduced from his essays, which are full of references to Don Quixote [4, 5].

The interest of physicians in Don Quixote may be, in part, a consequence of the fact that Cervantes treats medical questions in Don Quixote with outstanding accuracy [6], so that some have wondered whether he was actually a physician [7].

Excellent works on some of the medical conditions mentioned in Don Quixote exist [8-13]. However, to date, no one has yet tried a comprehensive study of the many references to neurology scattered throughout the text. In this work, we attempted to read Don Quixote from a neurologist's point of view, studying the neurological terms and conditions that appear in the novel, reviewing Cervantes' sources of neurological information, and hypothesizing whether Don Quixote's symptoms were actually due to a neurological disease. 


\section{Methods}

Both parts of El ingenioso hidalgo don Quijote de la Mancha were systematically read by both authors in order to identify references to neurology. After the screening phase, neurologic terms (such as 'palsy', 'tremor', 'head', 'faintness', etc.) were specifically searched in a digital version of the text. Discrepancies between authors were resolved with $100 \%$ agreement through discussion and consensus. The reading and the search were performed on a Spanish edition of the text [14], and later translated to English, following the English edition by J.M. Cohen [15].

\section{Neurological Conditions in Don Quixote}

Among the neurological signs and symptoms that appear in the course of Don Quixote are the following:

\section{Tremors}

There are more than 10 references to tremulous conditions, mostly related to the emotion of fear: 'I hung upon his words, my legs trembling under me so that I could scarcely stand' (part I, ch. 27); 'But she had hardly heard two lines, as the singer continued, when a strange trembling seized her, as if she were suffering from a severe attack of quartan ague' (part I, ch. 43); or related to the feeling of anxiety: 'Don Quixote, then, having risen to his feet, trembling from head to foot ..., said in a hurried, agitated voice, ...' (part II, ch. 32). However, in this context, tremor must not be considered a disease itself, but rather a physiologic consequence of the emotional circumstances of the plot. At that time, the heart was supposed to be the seat of emotions, and when these emotions were disturbed, the changes of the cardiac rhythm could reach the arms and the hands, giving rise to tremor. This conception was supported by several authors, including Juan de Barrios (1562-1645), who explained in the 34th chapter (entitled 'About palpitations, tremors and heart beats') of his work Verdadera medicina, cirugía y astrología (True medicine, surgery and astrology), published in Mexico in 1607, that 'tremor is a palpitation of the heart that can arise in any part [of the body]'. A similar view can be found in Quaestiones practicae, medicae et chirurgicae (1589) by Agustín Vázquez, Chair of Medicine at the University of Salamanca.

Throughout the novel, there are some curious mentions of mercury-induced tremor: '... at which spectacle Sancho began to shake like a man dosed with mercury, and Don Quixote's hair stood on end' (part I, ch. 19). Mercury was first used in the 16th century to treat syph- ilis, giving rise to the saying: 'One night with Venus, a lifetime with Mercury'. Mercury could be administered in the form of calomel (mercury chloride), an ointment, a steam bath or pill. Unfortunately, the side effects were as painful and terrifying as the disease itself. Many patients who underwent mercury treatments suffered from extensive tooth loss, ulcerations, and neurological damage (including epileptic seizures and tremors, such as the excerpt above). The use of mercury therapy continued until the first effective treatment, Salvarsan, was developed in 1910 by the immunologist Paul Ehrlich (18541915) [16].

\section{Sleep Disorders}

Don Quixote suffered from chronic insomnia due to ruminations and worries: 'Don Quixote did not sleep too much at all during the night, thinking about his lady Dulcinea' (part I, ch. 8); or 'on one of the nights he [Don Quixote] couldn't sleep ... he heard someone unlocking the door' (part II, ch. 48). Moreover, Cervantes points out that sleep deprivation contributed to the rise of Don Quixote's madness: 'and what with little sleep and much reading ... he lost his wits' (part I, ch. 1). In fact, at the end of the book, as Don Quixote is suffering from fever, 'his mind had been restored to him' after sleeping more than 6 hours (part II, ch. 54).

Insomnia was considered a severe disease by the medical literature of that time, as Blas Álvarez de Miraval admonishes in his book La conservación de la salud del cuerpo $y$ del alma (The improvement of the heal th of the body and soul), published in 1597: 'It is a very dangerous sign that a patient cannot sleep, during the day or the night, because sleep is essential for the relaxation of the senses' (ch. 23).

Snoring is also cited: '[Don Quixote] called to his squire Sancho, who was still snoring' (part II, ch. 20). Sancho also has the habit of taking long naps: 'Sancho replied that ... he did usually sleep four or five hours on a summer afternoon' (part II, ch. 32). The snoring, the lengthy siestas, and his obesity suggest that, though there are no references to episodes of cessation of breathing during sleep, Sancho may have had obstructive sleep apnoea.

Siesta, still a Spanish custom, was considered a healthy habit as Ivan Sorapán de Rieros (1572-1638) pointed out in his work Medicina española (Spanish medicine), published in 1616: 'Those who sleep at noon, even healthy or with any disease, should not change their habit.'

Finally, there is an episode where Don Quixote's sleep behaviour is altered; he is shouting and attacking some wineskins while dreaming that he is fighting a giant: 
'and in his right hand he held his unsheathed sword, with which he was slashing about on all sides, uttering exclamations as if he were actually fighting some giant: and the best of it was his eyes were not open, for he was fast asleep, and dreaming that he was doing battle with the giant' (part I, ch. 35).

This incident has been interpreted as a symptom of a rapid eye movement disorder [9]. Cervantes, through Sancho Panza, also explains the idea that sleep is a passive state, similar to death, where all mental activities are almost absent (part II, ch. 58). Theories of that time were unclear about the origin of sleep and the significance of dreams. Blas Alvarez de Miraval, in La conservación de la salud del cuerpo y del alma (ch. 23-26), specifies that 'According to Averroes, sleep comes from the heart, but according to Galen it is made in the brain'. And further on: 'Sleep is a condition in which the senses are not as free as in wakefulness, but not as held as in the deepest sleep [death].' Alvarez de Miraval also describes some sleep behaviour disorders, including somniloquy and somnambulism: 'Many people speak while sleeping, and they even respond to what they are asked. Some others wander around their room.'

\section{Neuropsychiatric Symptoms}

Episodes suggesting complex visual and auditory hallucinations include the famous struggle against the windmills: 'There you see about thirty outrageous giants, against whom I shall fight' (part I, ch. 8), and paranoid delusions: 'Enchanters have persecuted me, enchanters persecute me still, and enchanters will continue to persecute me' (part II, ch. 32); 'Did I not tell you, sirs, that this castle was enchanted, and that a legion or so of devils dwelt in it?' (part I, ch. 45).

\section{Dementia}

Cervantes portrays some of the characteristics of cognitive impairment, including disturbances of judgment: 'and what with little sleep and much reading his brains got so dry that he lost his wits' (part I, ch. I); time disorientation: 'three days passed in one hour' (part II, ch. 23); misidentification of people, such as the episode where he identified the modest priest of his town, an old acquaintance, as the 'Archbishop Turpin' (part I, ch. 7), and agitation: 'When they reached Don Quixote he was already out of bed, and was still shouting and raving, and slashing and cutting all round, as wide awake as if he had never slept' (part I, ch. 7). Cervantes also points out how Don Quixote frequently switched from aberrant behaviour to lucid intervals: 'His housekeeper and his niece noted that their master was sometime in his right senses' (part II, ch.
1); 'Don Quixote reasoned with so much direction that his two friends believed him in his right sense' (part II, ch. 1), and 'He is a mad man, full of lucid intervals' (part II, ch. 18).

Spanish physicians were interested in memory; for example, Blas Álvarez de Miraval, in La conservación de la salud del cuerpo y del alma (ch. 2), declares that 'memory and ingenuity are lost if they are not exercised'.

\section{Syncope}

Loss of consciousness in Don Quixote deserves itself a specific study, as it is outstandingly recurrent throughout the novel. Women are more prone to pass out, particularly in the context of a great emotion; often, episodes of loss of consciousness are rapidly reversible, suggesting a hysterical origin, which is evident in certain passages: ' $\mathrm{He}$ will sigh, she will swoon, and the damsel will fetch water, much distressed because morning approaches' (part I, ch. 21 ), and 'The bridegroom then approached to embrace his bride; and she, pressing her hand upon her heart, fell fainting in her mother's arms. ... They were all thrown into confusion by Luscinda's fainting, and as her mother was unlacing her to give her air ...' (part I, ch. 21). These women might be suffering from conversion disorder, although in other excerpts, a factitious origin of the loss of consciousness seems obvious: 'At this moment Camilla, throwing herself upon a bed that was close by, swooned away. ... Camilla was not long in recovering from her fainting fit and on coming to herself she said ...' (part I, ch. 34). '... the instant Altisidora saw him she pretended to faint, while her friend caught her in her lap, and began hastily unlacing the bosom of her dress' (part II, ch. 46). Intense physical and psychological activity may also trigger syncope: 'They rubbed him down, fetched him wine and unbound the shields, and he seated himself upon his bed, and with fear, agitation, and fatigue he fainted away' (part II, ch. 53).

Within the Spanish medical literature of that time, syncope is unusually well described in the last chapter of Tratado repartido en cinco partes principales que declaran el mal que significa este nombre: Peste (Treatise with five main parts in which the evil of this name is explained: Plague), published in 1601 by Ambrosio Nunes (15301611), a Portuguese physician (Portugal was a kingdom which formed part of the Spanish Empire at that time). Nunes explains that

'Syncope is a Greek term that means "faint". Of this, there are four differences: the first, "Echlysis", means "faint of spirit", because the sense and movement are not lost, but strength seems to fail. The second, "Lypothomia", means "faint", because intellect 
and movements are lost, although they are recovered promptly. The third, "Lypopsychia", is a kind of faint, with a similar duration, more or less. The fourth is "Syncope", in which strength seems to be knocked off.'

\section{Epilepsy}

There is a brilliant description of an epileptic patient:

'My son is possessed of a devil, and there is not a day but the evil spirits torment him three or four times; and from having once fallen into the fire, he has his face puckered up like a piece of parchment, and his eyes watery and always running; but he has the disposition of an angel, and if it was not for belabouring and pummelling himself he'd be a saint' (part II, ch. 47).

And there is also a brilliant description of an absence seizure in the character of Cardenio, a young man who was driven mad after his beloved Luscinda had married another man, and who lives alone in the Sierra Morena:

'But in the midst of his conversation he stopped and became silent, keeping his eyes fixed upon the ground for some time ...; and with no little pity, for from his behaviour, now staring at the ground with fixed gaze and eyes wide open without moving an eyelid, again closing them, compressing his lips and raising his eyebrows, we could perceive plainly that a fit of madness of some kind had come upon him; ... for he arose in a fury from the ground where he had thrown himself' (part I, ch. 20).

Some authors consider this excerpt to be an episode of functional neurological deficits in the context of a hysterical conversion disorder [17].

Epilepsy was well known by Spanish physicians of the Golden Age. Luis Lobera de Ávila (1480-1551), physician to Emperor Charles V, published in 1542 Remedio de cuerpos humanos (Remedies of human bodies) in which he explains the different terms given to epilepsy, including 'gota coral', 'morbus sacrum', 'morbus comicialis', and 'alpheresy'. Lobera de Ávila points out how 'primary causes of this disease can be to stare at the things that are moving around, and also strong smells. It is recognized because the paroxysmal episode lasts for little, ... and they have astonishing movements.' Some years later, in 1611, Francisco Pérez Cascales published Liber de Affectionibus puerorum, a treatise on pediatrics. It is divided into four chapters, the first of them about several diseases exposed 'a capite ad calcem' ('from head to feet'), including neurological diseases such as palsy, rabies, hydrocephalus, and epilepsy. He defines this latter one as the 'paroxysmal phenomenon in which all parts of the body suffer a seizure, and external and internal senses are lost'. Non-epileptic psychogenic seizures are also described with outstanding precision by Pérez Cascales, who explains that non-epileptic psychogenic seizures have a hysterical/uterine origin, and they are, in all cases, different from epilepsy as 'women are shocked by violent seizures in the whole body, they can see and listen, but they have lost the control of themselves due to the violent movements' [18].

\section{Paralysis (Perlesy, Apoplexy)}

The father of the epileptic patient described above (part II, ch. 47) wanted to engage his son to a paralytic girl: 'This son of mine who is going to be a bachelor, fell in love in the said town with a damsel called Clara Perlerina ...; and this name of Perlerines does not come to them by ancestry or descent, but because all the family are paralytics' (part II, ch. 47). Some have hypothesized that the cause of the palsy in this family may have been a smallpox epidemic [19], but other hereditary diseases, such as spastic paraparesis, could be considered.

Cervantes could be describing a wake-up stroke in the next extract: 'nobody knows what will happen; ... many a one goes to bed in good health who can't stir the next day' (part II, ch. 19). However, specific allusions to apoplexy are not found in Don Quixote.

During the 16th and 17th centuries, perlesy was considered a consequence of the obstruction of the nervous flow, due to a thick humour or a tumour. Jerónimo Soriano (1560-?), in his work Método y orden de curar las enfermedades de los niños (Method and order to heal the diseases of the children) classifies perlesy into 'perfect, in which sensation and movement are lost; less perfect, in which only movement is lost; and imperfect, in which only sensation is lost'.

Preventive measures of stroke were already known; for example, Lobera de Ávila, in Remedio de cuerpos humanos, points out that 'the causes of apoplexy are to stuff oneself with foods and delicacies, even in spite that they are good, because they thicken the blood and the humours'.

\section{Traumatic Head Injury}

Head trauma is frequently encountered in Don Quixote, mostly as a consequence of struggles and fights:

'dropping his buckler he lifted his lance with both hands and with it smote such a blow on the carrier's head that he stretched him on the ground ... Shortly after this, another ... came with the same object of giving water to his mules ... when Don Quixote ... once more dropped his buckler and once more lifted his lance, and without actually breaking the second carrier's head into pieces, made more than three of it, for he laid it open in four' (part I, ch. 3); 'The cuadrillero ... lost his temper, and raising the lamp full of oil, smote Don Quixote such a blow with it on the head that he gave him a badly broken pate' (part I, ch. 17); 'And lifting his 
pike, which he had never let out of his hand, [Don Quixote] delivered such a blow at his head that, had not the officer dodged it, it would have stretched him at full length' (part I, ch. 45), and 'The unlucky wight did not speak so low but that Roque overheard him, and drawing his sword almost split his head in two' (part II, ch. 60).

Cervantes seems to be describing a basilar skull fracture in the next excerpt: 'Grasping his sword more firmly with both hands, he came down on the Biscayan with such fury, smiting him full over the cushion and over the head, that as if a mountain had fallen on him, he began to bleed from nose, mouth, and ears' (part I, ch. 9).

\section{Headache}

As pointed out in previous works [10], almost 100 references to pain can be found in Don Quixote; however, specific allusions to headache are scarce: 'I mean to say, that when the head suffers all the members suffer' (part II, ch. 2). This excerpt has some similarities to Dionisio Daza Chacón's (1510-1596) theory of pain, in his Práctica $y$ teórica de cirugía (Practice and theory of surgery), where he points out that 'the part which is having the pain is not feeling the pain, because it is the brain the only one that feels; The pain is not in the foot, but in the brain, which is the one that feels'.

Throughout Don Quixote, headache is usually a consequence of traumatic injury: 'Don Quixote, who, with his hand to his head, was bewailing the pain of the blow of the lamp' (part I, ch. 17).

\section{Other Diseases}

A curious description of pica (the compulsive desire to eat materials such as soil, clay, plaster, etc.) can be found: 'I am now labouring under that infirmity which women sometimes suffer from, when the craving seizes them to eat clay, plaster, charcoal, and things even worse, disgusting to look at, much more to eat' (part I, ch. 33). This compulsive behaviour can be present in pregnant women as well as in neuropsychiatric disorders, such as autism, schizophrenia, or Kleine-Levin syndrome. Cervantes also describes what could be considered a heat stroke: 'and all the while he rode so slowly and the sun mounted so rapidly and with such fervour that it was enough to melt his brains if he had any' (part I, ch. 2). Syphilis is mentioned too: '[Virgilius] forgot to tell us who was the first man ... to try salivation for the French disease' (part II, ch. 22). In Cervantes' day, syphilis was termed 'the French disease' in Spain, and 'the Spanish disease' in France.

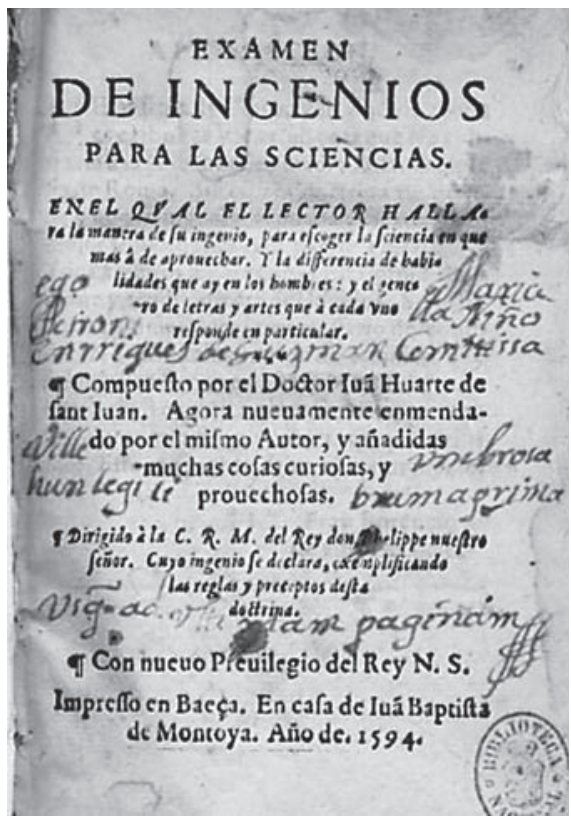

Fig. 3. Juan Huarte de San Juan published the first edition of his Examen de ingenios in 1575, which won him a European reputation. Though now superseded, Huarte's treatise is historically interesting as the first attempt to show the connection between psychology and physiology. Despite its initial proscription by the Inquisition, the Examen became popular in Spain and Europe. In fact, in 1594, after Huarte de San Juan's death, a second, revised and expurgated version was printed (image shown).

\section{Cervantes' Neurological Sources: Neurology during the Spanish Golden Age}

There are some factors that explain Cervantes' medical knowledge. First, there is evidence that, while he was living in Seville, Cervantes frequently visited the Hospital de Inocentes, a mental asylum that served as a holding place for the mentally disabled, criminally insane, epileptics, and the poor [20].

Secondly, he was born in a family of physicians: his father, Rodrigo de Cervantes (1509-1585), was a surgeonbleeder, and his sister, Andrea de Cervantes (1545-1609), was a nurse [21], suggesting that he grew up in a medical atmosphere. Moreover, many of Cervantes' friends were acclaimed physicians [21] such as Francisco Díaz (15271590), who wrote a treatise on urology [22], and Antonio Ponce de Santa Cruz (1561-1632), physician to King Philip III and King Philip IV, who published, in 1631, a treatise on epilepsy [23].

Cervantes lived during the late 16th and early 17 th centuries, known as the Spanish Golden Age, a period of 
Fig. 4. Front cover of the first edition of Libri sex by Andrés Alcázar, printed in 1575 (left). The first chapter of this book, entitled 'De Vulneribus capitis', included some curious illustrations about different types of head injuries (right).
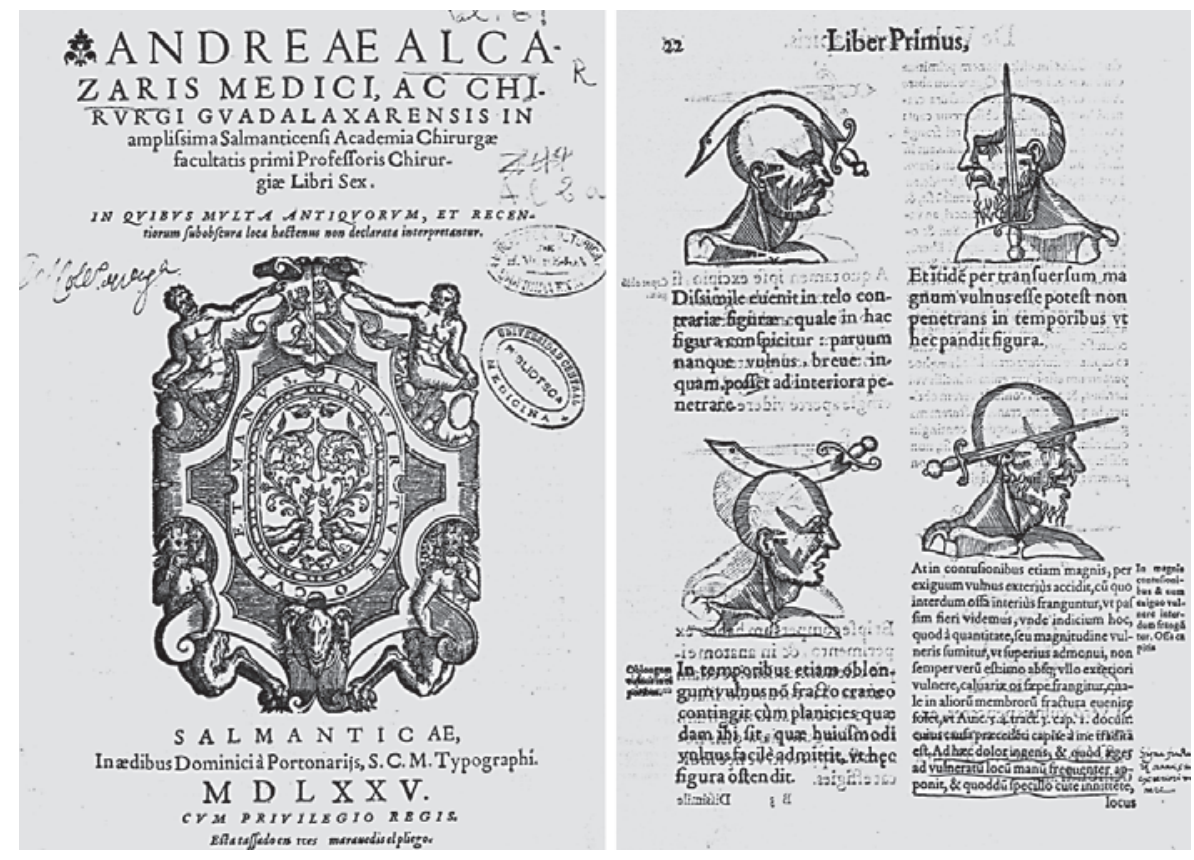

flourishing in painting (with leading artists such as El Greco, Ribera, Velázquez, Murillo, and Zurbarán); music (with outstanding composers such as Tomás Luis de Victoria, Francisco Guerrero, and Cristóbal de Morales), and literature (with Lope de Vega, Calderón de la Barca, and Cervantes himself). The Spanish Empire was global, and the influence of Spanish culture was so ubiquitous that Spanish is still the native tongue of approximately 500 million people. Also, the Spanish hegemony was patent in technical, social and biological sciences, and Spanish physicians led Western medicine too [24, 25].

In this context, there is evidence that Cervantes owned a private library with more than 200 volumes, including medical books written by acclaimed Spanish physicians [26]. One of these volumes was Examen de ingenios (The examination of men's wits), written by Juan Huarte de San Juan (1529-1588) (fig. 3). This immortal and unique work, printed in 1575, reprinted at least 80 times, and translated into seven languages [27], is considered a founding work of neuropsychology, as Huarte strove to establish the relationships between brain, temper, and ingenuity from a mechanistic point of view [28]. Interestingly, some of the paragraphs of the Examen de ingenios can be found, virtually word for word, in Don Quixote [29]; even the title (The ingenious gentleman Don Quixote de la Mancha) is obviously based on it.

Cervantes also owned a copy of the work Práctica $y$ teórica de cirugía (Practice and theory of surgery), pub- lished in 1584 by Dionisio Daza Chacón (1510-1596), surgeon to Emperor Charles V, to his son King Philip II and close friend of Vesalius. In 1569, Daza Chacón was appointed physician to Don Juan de Austria (King Philip's illegitimate half-brother) and served him, as chief surgeon, during the Battle of Lepanto, which took place on October 7, 1571, when a fleet of the Holy League, a coalition of southern European Catholic states leaded by Spain, decisively defeated the main fleet of the Ottoman Empire. Given that Cervantes took part in this battle and received three gunshot wounds (two in the chest and one which rendered his left arm useless), it is possible that Daza Chacón assisted him [30].

At the same time, Andrés Alcázar (approximately $1490 \sim 1585)$ made crucial contributions to the understanding of traumatic head injury; in 1575, he published, in Latin, Libri sex, a compilation of six books, the first of them entitled De vulneribus capitis (About head injury), considered the first modern treatise on neurosurgery [30] (fig. 4).

Other important physicians of that time include Miguel Sabuco (1525-1588) who published Nueva filosofía (New philosophy) in 1587, where he explained the theory of the 'succo nervoso' (nervous sap, or original neurotransmitter substance) [31]; Juan Valverde de Amusco (1525-1564), considered the most important anatomist of the 16th century, who published in 1556, in Rome, Historia de la composición del cuerpo humano 
Fig. 5. Valverde de Amusco's Historia de la composición del cuerpo humano was first published in Rome in 1556. This work is profusely illustrated with 42 copperplate engravings, probably done by Gaspar Becerra (1520-1570). In this work, Valverde corrected and improved the depictions of the muscles of the eyes, middle ear, nose, and larynx previously made by Andreas Vesalius in De humani corporis fabrica. The most astonishing engraving is that of a muscle figure holding his own skin in one hand and a knife in the other, which has been likened to Saint Bartholomew in 'The Last Judgment' (by Michelangelo) of the Sistine Chapel (left). There is also an engraving with axial sections of the brain, describing the meninges and cerebral ventricles (right).

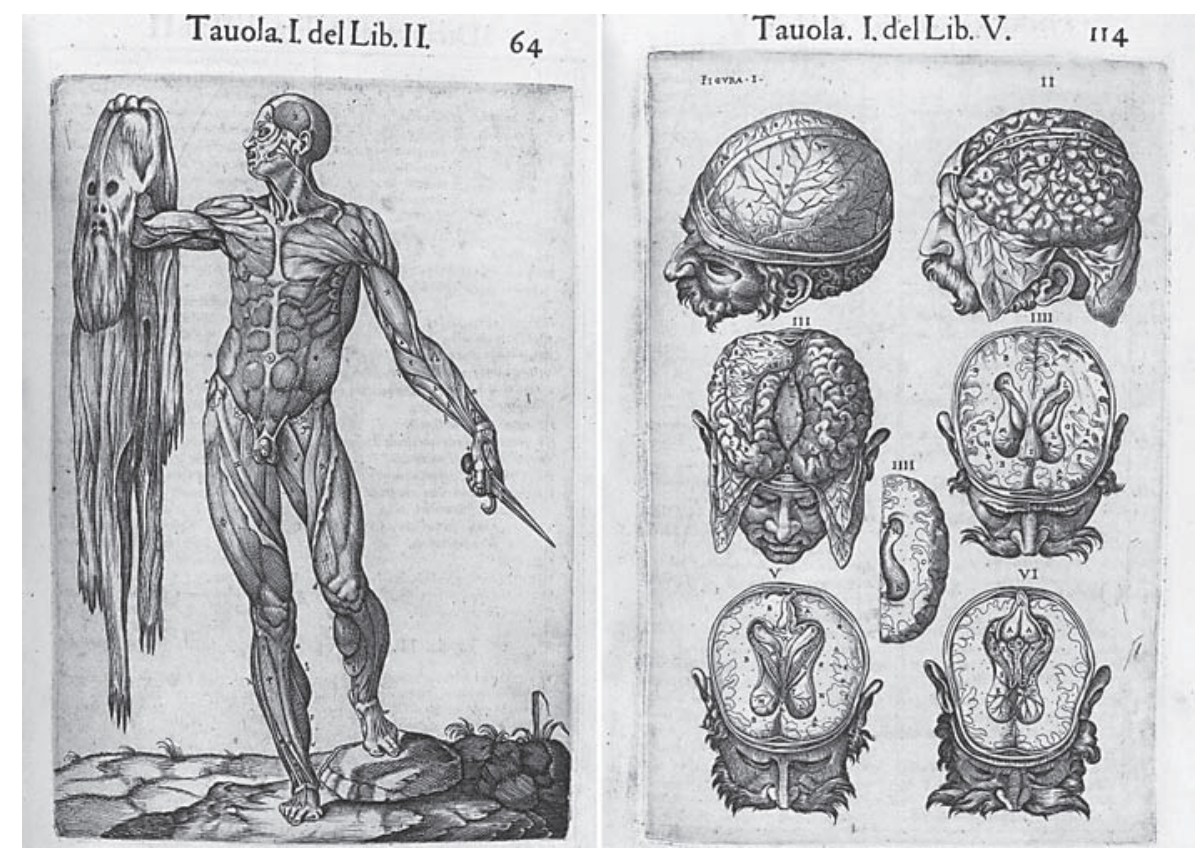

(History of the composition of the human body), where he offers the first depiction of the intracranial course of the carotid arteries (several decades before Willis's description), the extrinsic ocular muscles, and the middle ear bones, particularly the stapes (fig. 5); Gómez Perea (1500?) who published, in 1554, Antoniana Margarita, where he studied brain function from a mechanistic perspective, explaining his theory about the 'automatism of animals' and describing what can be considered the first depiction of the reflex arc and the conditional reflex [32], and Juan Bravo de Piedrahita (1527-1610) who published the first known treatise on chemical senses physiology in 1583, entitled De saporum et odorum differentiis, developing a coherent theory of how olfaction and taste operate.

Unfortunately, due to complex reasons, cutting-edge Spanish science during the first half of the 16th century collapsed in the last years of the century. King Philip II, in his attempt to keep the purity of the Catholic Faith against Lutheranism and Calvinism, decreed, in a Royal Law given on September 7, 1558, 'the ban of importing books into the kingdoms of Castile, under death penalty'. An additional Royal Law, given on November 22, 1559, prohibited scholars 'to go abroad of our kingdoms of Castile to study, teach, learn or live in universities, colleges or schools outside these kingdoms, allowing a time span of four months for those who are abroad to come back, under severe penalties'. This ban of studying outside the
Spanish peninsula, except in Naples, Rome and Bologna (dominions under the Spanish Empire or without Lutheran or Calvinist influence), became a severe shortcoming for the acquisition and renovation of the scientific knowledge in Spain. Due to these restrictions, a new Royal Law, launched on August 2, 1593, ordered that 'all physicians and surgeons must take an exam of the list of topics appearing in "Institutiones Medicae", written in 1594 by Luis Mercado (1525-1611), personal physician to King Philip II, 'and they will be encouraged to learn it by heart' (fig. 6).

Eventually, during the 17th century, Spain definitely lost its hegemony and moved away from the new emerging European knowledge that would form the underpinnings of the scientific revolution [33].

\section{Don Quixote's Disease}

Since the 19th century, several authors have discussed the disease that Don Quixote appears to be suffering from. The first author who did so was Philippe Pinel (1745-1826), followed immediately by many others. They all agreed in diagnosing Don Quixote as 'monomaniac'. After Emil Kraepelin (1856-1926), the old Pinelian nosography was substituted by a new system of classification of mental disease, and Don Quixote was then considered 'paranoid'. Other have hypothesized that, as his 
Fig. 6. Portrait of a doctor (presumed portrait of Luis Mercado) by Doménikos Theotokópoulos, 'El Greco' (approximately 1580), oil on canvas, that can be seen in the Prado Museum (left). Front cover of the first edition of Institutiones Medicae by Luis Mercado (1594), commissioned by King Philip II to serve as a syllabus for the examination of physicians and surgeons in Spain (right).
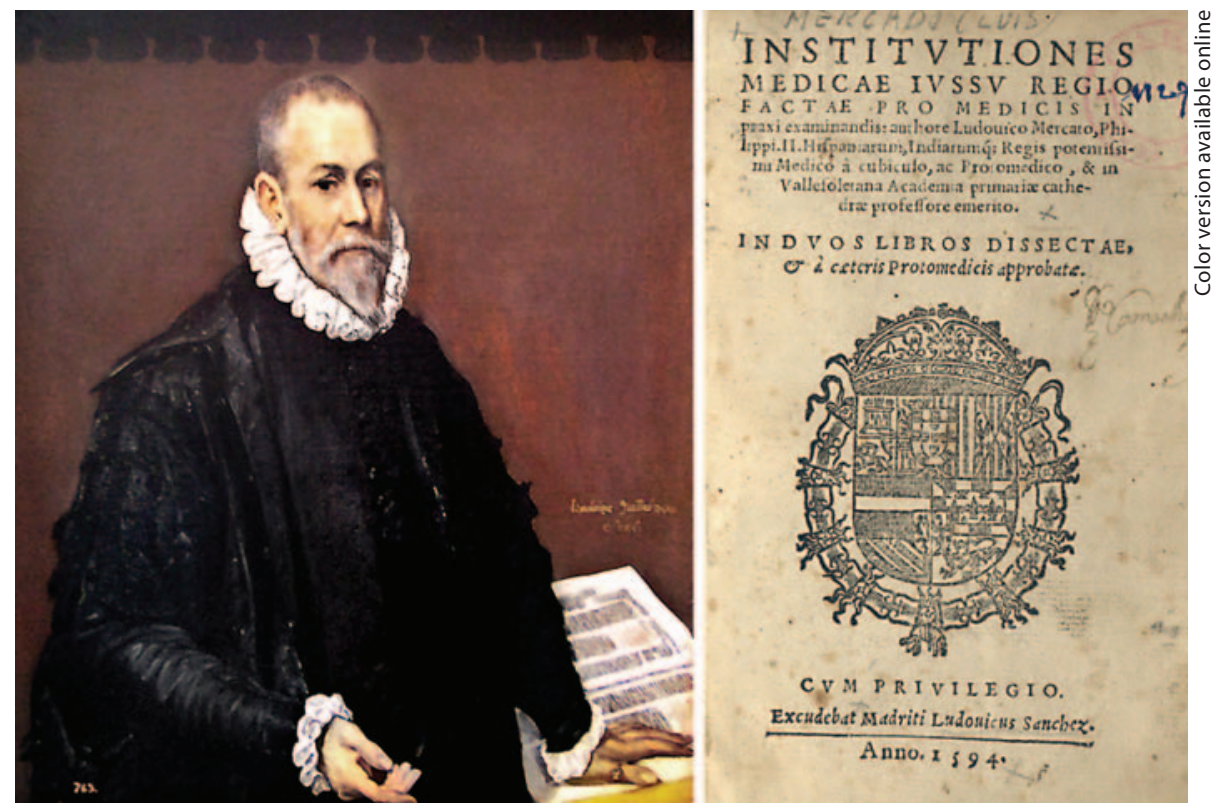

squire Sancho Panza accepted and completely shared Don Quixote's delusional ideas of greatness, this was a case of folie à deux [34]. Finally, after DSM-IV, the usual diagnosis is 'delusional disorder' [35], though psychosexual [13] or even non-psychiatric interpretations have been proposed.

As Cervantes also provides information on diet and sleep patterns in the novel, some authors have assumed that Don Quixote's disease was completely a consequence of sleep deprivation and malnutrition, assuming that the hidalgo was deficient in calcium, vitamin C, vitamin E, and suffered from osteoporosis, scurvy, and cerebellar dysfunction [36].

As mentioned above, Don Quixote had visual and auditory hallucinations, symptoms suggestive of cognitive impairment and rapid eye movement sleep behaviour disorder, fulfilling clinical diagnostic criteria for probable dementia with Lewy bodies [37]. Cervantes might have witnessed a real patient with dementia with Lewy bodies and translated him into the character of Don Quixote.

Finally, there is also a theory that Don Quixote was not mad at all, but a gentleman with solid ideas who, willingly, wanted to be madly loyal to his convictions and duties, and chose a particular way of life for that reason. As Don Quixote says, 'each of us is the maker of his own Fortune' (part II, ch. 66), and he adds, 'I know who I am' (part I, ch. 5) $[38,39]$. Santiago Ramón y Cajal agreed with this vision, as we can deduce from the speech he gave at the Medical College of San Carlos in 1905 (a year before he was awarded with the Nobel Prize in Physiology or Medicine) entitled 'Psychology of Quixote and Quixotism'. In this text, Cajal considers the hidalgo 'an ideal of humanity, magnificence, and justice', and suggested that these values, instead of being symptoms of disease, must always be involved in the true scientific spirit [5].

However, retrospective diagnosis of patients who lived centuries ago is not simple, particularly if they are fictional characters. Questions such as whether the German mystic Saint Hildegard of Bingen suffered from migraine [40], Emperor Julius Caesar had epilepsy [41], or Don Quixote had dementia with Lewy bodies are wonderful and amusing hypotheses, but lack solid and definite evidence.

\section{Concluding Remarks}

Interpretations of Don Quixote from the perspective of current medical disciplines may run the risk of turning into mere speculation. This was noted by the distinguished Spanish philosopher and novelist, Miguel de Unamuno (1864-1936), who wrote: 'of all the commentators of Don Quixote, there are none more terrible than doctors: they go so far as to analyze the type of madness from which Don Quixote was suffering, its aetiology, its symptoms and even its therapy' [42]. 
In any case, our aim in this work was not to pontificate, but rather to analyse and study the neurological signs and symptoms mentioned in this great novel, in the context of the neurological knowledge of that time, highlighting that, although Cervantes wrote it four centuries ago, the ideas and concepts reflected in Don Quixote are still of interest. Our work also shows how the considerable extent of Cervantes's medical knowledge contributed to his extremely accurate description of symptoms in this novel.

This is demonstrated not only in Cervantes' precise depiction of neurological conditions, but also in his recommendation to deepen our understanding of disease, since 'the beginning of health lies in knowing the disease and in the sick man's willingness to take the medicines which the physician prescribes' (part II, ch. 60). Moreover, scientists in general and physicians in particular must not be personally affronted or discouraged from further research just because, in part II, ch. 22, Don Quixote admonishes: 'for there are some who weary themselves out in learning and proving things that, after they are known and proved, are not worth a farthing to the understanding or memory.'

\section{Acknowledgements}

We would like to dedicate this work to the distinguished scholar Luis S. Granjel, Prof. Emeritus of History of Medicine of the University of Salamanca, essential reference for any study about Don Quixote and medicine, to whom the authors are indebted for his mentorship and guidance throughout the last decades.

\section{Disclosure Statement}

The authors declare no conflict of interests.

\section{References}

1 Johnson S: Lives of the English poets. Ocala (Florida), Atlantic Publishing, 2000.

2 Jock Murray T: Read any good books lately? MJM 2009;12:90-91.

3 Freud E: Letters of Sigmund Freud. New York, Basic Books, 1960.

4 Ramón y Cajal S: El mundo visto a los ochenta años: impresiones de un arterioesclerótico. Madrid, Espasa-Calpe, 1960

5 Ramón y Cajal S: La psicología de los artistas. Madrid, Espasa-Calpe, 1972.

6 Ife B: Sickness and health in the work of Cervantes. Clin Med 2007;7:608-610.

7 Simini B: Miguel de Cervantes, hydropsy, and Thomas Sydenham. BMJ 2001;323:1293.

-8 Saenz-Santamaria MC, Garcia-Latasa FJ, Gilaberte Y, Carapeto FJ: Dermatologic diseases in Don Quixote: skin conditions from Cervantes' pen. Int J Dermatol 1995;34:212215.

-9 Iranzo A, Santamaria J, de Riquer M: Sleep and sleep disorders in Don Quixote. Sleep Med 2004;5:97-100.

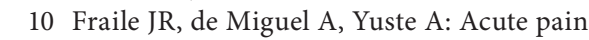
in 'Don Quixote'. Rev Esp Anestesiol Reanim 2003;50:346-355.

-11 López-Muñoz F, Alamo C, García-García P: 'The herbs that have the property of healing...,: the phytotherapy in Don Quixote. J Ethnopharmacol 2006;106:429-441.

12 Beá J, Hernández V: Don Quixote: Freud and Cervantes. Int J Psychoanal 1984;65:141153.

13 Granjel LS: Medical approach to 'the Quixote'. An R Acad Nac Med (Madr) 2005; 122: 131-143; discussion 143-145.
14 Cervantes Saavedra M: Don Quijote de la Mancha. Madrid, Edaf, 1999.

15 Cervantes Saavedra M: Don Quixote (Translated by J.M. Cohen). London, Penguin Classics, 1970.

16 Dayan L, Ooi C: Syphilis treatment: old and new. Expert Opin Pharmacother 2005;6: 2271-2280.

17 Bailón JM: La psiquiatría en El Quijote. El diagnóstico de ayer y de hoy. Barcelona, Ars Medica, 2006.

18 García-Albea E: Epilepsy in the Spanish Renaissance. The work of Pérez Cascales of Alcalá. Rev Neurol 1999;29:467-469.

19 Iniesta I: Neurology and literature. Neurologia 2010;25:507-514.

20 Alonso-Fernandez F: Dos especies psicopatológicas. Don Quijote y el Licenciado Vidriera. Torre de los Lujanes, Boletín de la Real Sociedad Económica Matritense de Amigos del País 2005;56:45-64.

21 Lopez-Munoz F, Alamo C, Garcia-Garcia P: The mad and the demented in the literary works of Cervantes: on Cervantes' sources of medical information about neuropsychiatry. Rev Neurol 2008;46:489-501.

22 Bush RB, Bush IN: Francisco Diaz and the World of Sixteenth Century Urology. Section of History of Medicine. Chicago, Chicago Medical School, 1970

23 García-Albea E: Praelections Valliosoletanae (1631) by Antonio Ponce de Santa Cruz, the first major Spanish treatise on epilepsy. Rev Neurol 1998;26:101-105.

24 Lopez Piñero JM: La medicina en la historia. Madrid, La Esfera de los Libros, 2002.
25 Price R: Spanish medicine in the Golden Age. J R Soc Med 1979;72:864-874.

26 Eisenberg D: Did Cervantes have a library?; in Miletich JS (ed): Hispanic Studies in Honor of Alan D. Deyermond: A North American Tribute. Madison, Hispanic Seminary of Medieval Studies, 1986.

27 Granjel LS: Juan Huarte y su 'Examen de ingenios'. Salamanca, Academia de Medicina, 1988.

28 Martín-Araguz A, Bustamante-Martínez C: The examination of men's wits by Juan Huarte de San Juan, and the dawn of the neurobiology of intelligence in the Spanish renaissance. Rev Neurol 2004;38:1176-1185.

29 Salillas R: Un gran inspirador de Cervantes: el doctor Juan Huarte y su 'Examen de Ingenios'. Madrid, Victoriano Suarez, 1905.

30 Granjel LS: Cirugía Española del Renacimiento. Salamanca, Seminario de Historia de la Medicina Española, 1968.

31 Martin-Araguz A, Bustamante Martinez C, Fernandez Armayor V: Sabuco's suco nerveo and the origins of neurochemistry in the Spanish Renaissance. Rev Neurol 2003;36: 1190-1198.

32 Martín-Araguz A, Bustamante-Martínez C, Fernández-Armayor Ajo V, Moreno-Martínez JM, Olmedilla-González N, García De La Rocha ML, Sierra-Sierra I: Antoniana Margarita: Gómez Pereira, Francisco Lobato and the antecedents of cerebral mechanicism during the Spanish renaissance. Rev Neurol 2001;33:82-89.

33 Suárez Fernández L: La crisis de la hegemonía española, siglo XVII. Madrid, Rialp, 1991. 
-34 Kumar V: Don Quixote and Sancho Panza: folie a deux? Br J Psychiatry 2011;198:326327.

35 Granjel LS: Los médicos ante el Quijote. Medicina e Historia 1976;56:7-26.

36 Ife B: Don Quixote's diet. Bristol, University of Bristol Hispanic Studies, 2001.

37 García Ruiz PJ, Gulliksen L: Did Don Quixote have Lewy body disease? J R Soc Med 1999;92:200-201.
38 Castro A: El pensamiento de Cervantes y otros estudios cervantinos. Madrid, Trotta, 2002.

39 Gracia Guillén D: Discreet follies. Variations on Don Quixote's folly. An R Acad Nac Med (Madr) 2005;122:105-121; discussion 121129.
40 Podoll K, Robinson D: The migrainous nature of the visions of Hildegard of Bingen. Neurol Psychiat Brain Res 2002;10:95-100.

41 Hughes JR: Dictator Perpetuus: Julius Caesar - did he have seizures? If so, what was the etiology? Epilepsy Behav 2004;5:756-764.

42 Unamuno M: El caballero de la triste figura. Madrid, Austral, 1970. (The original lecture, entitled 'La locura de Don Quijote', was given in Salamanca on April 10, 1905.) 